findings could have been due to bias. The World Health Organisation is studying the risk of cancer in women using medroxyprogesterone at centres in Thailand, Kenya, and Mexico. ${ }^{3}$ The most recent report from this case-control study (based on 39 cases who had used medroxyprogesterone) yielded a relative risk for all women using the drug of 1.0 ( $95 \%$ confidence interval 0.7 to $1 \cdot 5){ }^{3}$ Relative risks were not shown separately for women diagnosed as having breast cancer before age 35, for women who used the drug before age 25 , or for women who reported using it recently; it will be important to see whether more detailed analyses replicate our findings and, if so, which of these groups are specifically at risk.

If our results are confirmed the indications for using medroxyprogesterone will need to be reassessed. The findings will also contribute to discussions about the relevance of the beagle model and about the pathogenesis of breast cancer.

This research was supported by grants from the Medical Research Council of New Zealand and from the World Health Organisation's special programme of research, development, and research training in human reproduction. We thank Mrs Celia Harris and Mrs Janet Thomson (the interviewers); Mrs Judith Smeijers, Mrs Isabel Pairman, and Mr Peter Herbison $\mathrm{Mr}$ Jim Fraser and Miss Jackie Auld of the National Cancer Registry; Professor Ronald Kay, Miss Barbara Mason, and Mrs Lorraine Neave of the Auckland Breast Cancer Study Group; and the women who participated in the study and the surgeons and general practitioners who supported it.
1 World Health Organisation. Facts about injectable contraceptives: memo randum from a W'HO meeting. Bull W'HO 1982:60:199-210.

2 Weisz J, Ross (iT, Stolley PD. Report of the public hourd of inquiry on Depe Prowera. Reckville, Maryland: L'nited States Food and Drug Administra tion, 1984

3 World Health (Organisation. Depot-medruxyprogesterone acetate (1)MPA and cancer: memorandum from a WHO meeting. Bull WHO 1986;64: $375-82$.

4 Lee NC, Rosero-Bixby L, Oberle MW, Grimaldo C, Whatley AS, Rovira EZ A case-control study of breast cancer and hormonal contraception in Costa Rica. 7 N ( : $1987: 79: 1247-54$

5 Paul C, Skegg DCG, Smeiiers J. Spears GFS. Contraceptive practice in New Zealand. W\%. Hed 7 1988;101:809-13.

6 Paul C, Skegg DC, (i, Spears GFS, Kaldor JM. Oral contraceptives and breast cancer: a national studv. Br.Med F 1986;293:723-6.

7 Skegg DCG. Potential for bias in case-control studies of oral contraceptives and breast cancer. Am 7 Epidemiol 1988:127:205-12.

8 Miller AB, Bulbrook RD. UICC multidisciplinary project on breast cancer: the epidemiology, aetiology and prevention of breast cancer. Int 7 Cancer $1986 ; 37: 173-7$

9 Bruzzi P, Negri E, La Vecchia C, et al. Short term increase in breast cancer risk following a full term pregnancy. Br. Hed f.1988;297:1096-8.

10 Hall PE. Long-acting injectable formulations. In: Diczfalusv E, Bvgdeman $\mathrm{M}$, eds. Fertility regulation today and tomorrow. New York: Raven Press. 1987:119-41. (Serono symposia publications, vol 36 .

11 Korenman SG. Oestrogen window hypothesis of the aetiology of breast cancer. Lancet 1980;i:700-1.

12 Henderson BE, Ross RK, Judd HL, Krailo MD, Pike MC. Do regular ovulatory cycles increase breast cancer risk? Cancer 1985;56:1206-8.

Pike MC. Ross RK. Breast oncer. Br Med Bull 1984:40:351-4.

14 Briggs $M$. The beagle dog and contraceptive steroids. Life Sci 1977;21:275-84

15 Fraser IS, Weisherg E. A comprehensive review of injectable contraception Fraser IS, Weisherg E. A comprehensive review of injectable contraception
with special emphasis on depot medroxyprogesterone acetate. Hid $\mathcal{f}$. Aust

16 Greenspan AR, Hatcher RA, Moore M, Rosenberg MJ, Ory HW. The association of depo-medroxyprogesterone acetate and breast cancer. (omtraception 1980;21:563-9.

17 Liang AP, Levenson AG, Layde PM, et al. Risk of breast, uterine corpus, and ovarian cancer in women receiving medroxyprogesterone injections. $7 \mathrm{AMA}$ $1983 ; 249: 2909-12$.

Accepled 3 fuly 1989

David E Neal, Peter D Ramsden, Linda Sharples, Andrew Smith, Phillip H Powell, Rosemary A Styles, Ralph J Webb

Abstract

Objectives-To determine the symptomatic and to establish whether the outcome is influenced or can be predicted by preoperative urodynamic measurements.

Design-Prospective non-randomised study with follow up at a mean of 11 months after operation.

Department of Urology, Freeman Hospital, Newcastle upon Tyne NE7 7DN

David E Neal, FRCS, senior lecturer in urological surgery Peter D Ramsden, FRCS, consultant urologist Phillip H Powell, FRCS, consultant urologist Rosemary A Styles, FRCS, senior urological registrar Ralph J Webb, FRCS, urological research fellow

Medical Research Council Biostatistics Unit, Cambridge

Linda Sharples, PHD, lecturer in statistics

Whickham, Tyne and Wear Andrew Smith, FRCGP, general practitioner

Correspondence to: Mr Neal.

BrMed F 1989;299:762-7

Intervention-Elective prostatectomy.

Main outcome measure-Classification on the basis of relief of symptoms assessed by patients and urologist and general practitioner and of symptom scores obtained by questionnaire.

Results - Of the 217 men followed up, $171(79 \%)$ had a satisfactory subjective review and $155(72 \%)$ had a satisfactory review and also low symptom scores. An unsatisfactory outcome was associated with preoperative symptoms of urge incontinence, small prostatic size and resected weight, low voiding pressures, and low urethral resistance. Preoperative maximum urinary flow rates did not predict outcome. Men with poor outcome could be classified into two groups: those with irritative symptoms who were more likely before operation to have had urge urodynamic outcome of elective prostatectomy and

incontinence and detrusor instability and men with symptoms of poor urinary flow who were more likely before operation to have had a small prostate, low voiding pressures, and low urethral resistance. In patients in the second group flow rates or voiding pressures improved little after operation. Men with stable detrusors and either low urethral resistance or low voiding pressures were less likely to do well after prostatectomy, but despite these associations preoperative urodynamic measurements were unable to predict outcome accurately.

Conclusions-Prostatectomy was satisfactory in relieving symptoms and improving urodynamic measurements in most men, but even in those with classic symptoms and low urinary flow rates a substantial minority experienced little improvement afterwards and urodynamic measurements did not accurately predict outcome in individual patients. brovascular disease; $217(86 \%)$ were followed up

\section{Introduction}

Men in their 40s contemplating the one in 10 chance of future prostatectomy ${ }^{2}$ will be reassured that the operation is safe ${ }^{3}$ but may be disquieted by recent reports, which found that a fifth of men required a second transurethral operation within eight years, ${ }^{+}$that many experienced little improvement in quality of life assessment, ${ }^{5}$ and that persistent urinary problems were commonplace. ${ }^{6}$

In about a fifth of men prostatectomy is performed for acute or chronic retention of urine,, 7 but in the remainder it is carried out for symptoms of bladder outflow obstruction that are difficult to assess. Moreover, similar symptoms may be produced by an un- 
obstructed and poorly contracting or unstable detrusor. Measurement of maximum urinary flow rates may identify men with obstruction who are likely to do well after prostatectomy. ${ }^{\mathrm{x}}$

Several reports of urodynamic findings before and after prostatectomy have been published, ${ }^{y-12}$ but most included only few men and some included men with acute retention of urine, whose preoperative urodynamic findings may be difficult to interpret. Moreover, none stated clearly the methods of defining outcome based on symptoms and urodynamic findings.

In 1984 we set up the present study ${ }^{131+}$ to determine the outcome based on symptoms and urodynamic measurements of elective prostatectomy, to determine the proportion of men whose poor urinary flow was associated with normal or low pressure voiding, and to test the hypothesis that men with normal or low pressure voiding before operation have a less successful outcome after operation. We also wished to determine whether urodynamic measurements were useful in predicting the outcome of elective prostatectomy.

\section{Patients and methods}

Men listed for prostatectomy between January 1985 and September 1986 were asked to take part. We aimed at studying only men who were clear candidates for elective prostatectomy, ${ }^{13}$ and the following were excluded: men already on a waiting list (because those waiting for some time might not have been representative), men with acute retention, men with clinically apparent prostatic cancer, and men with neurological or cerebrovascular disease. The indications for operation were symptoms of poor flow, hesitancy, dribbling micturition, or incomplete bladder emptying with or without additional symptoms of frequency, nocturia, urgency, or urge incontinence. All had a maximum urinary flow rate $<15 \mathrm{ml} / \mathrm{s}$ when measured in the outpatient department.

Two hundred and fifty three men were studied before their operation, ${ }^{1314}$ and their urodynamic findings were not reported back to the referring clinician. After operation 217 men (86\%) aged 48-97 (mean 69) were studied. Of the 36 men not studied, seven never had an operation, eight died before follow up (one postoperatively and seven incidentally after leaving hospital), and 21 did not attend the special follow up clinic. The length of history before operation was $2 \cdot 3$ years (range 3 months to 15 years). Consultant urologists listed 89 of the patients for operation and operated on 100; the remainder were listed either by senior registrars $(50)$ or urological registrars (78) and operated on by senior registrars (74) or urological registrars (43). Transurethral prostatectomy was performed in 189 men, and the mean weight of tissue after formalin fixation was 23 (SD 24) $\mathrm{g}$ (range 5-140 g). Of the remainder (28), nine had either retropubic prostatectomy (weight of tissue removed 60-180 g) and 19 had transurethral incision of the bladder neck and prostate. The size of the prostate measured by ultrasonography before transurethral prostatectomy in the 120 men in whom scanning was performed was 48 (range 8-240) $\mathrm{ml}$, and resected weight and preoperative prostatic volume were significantly correlated $(r=0.74$; $p<0.001)$. Twenty four patients had incidental prostatic cancer on histological examination.

\section{METHODS}

The methods of performing the urodynamic study have been reported previously. ${ }^{13}$ The terminology used is that of the International Continence Society," and detrusor pressure at maximum flow was taken as being representative of voiding pressure. A standard questionnaire was used to measure obstructive and irritative symptoms (each scored out of a maximum of
$10)^{13}$ and was based on that described by FrimodtMoller et al. ${ }^{16}$ The patients were reviewed routinely about six weeks after their operation.

Two hundred and seventeen men were reviewed at least once more and at least three months after operation by a urologist (mean time 11 months, range 2-27 months), but most (164) were reviewed twice more. Of the 217 men, 10 agreed only to the review of symptoms, 26 men also had urinary flow rate and residual urine measured, and the remaining 181 had a full urodynamic evaluation.

Classification of outcome based on symptoms-At the final review the questionnaire was completed. After asking patients whether residual symptoms interfered with their usual activities they were placed in one of five categories (I no residual symptoms; II considerably improved but a few symptoms not interfering with usual activities; III improved but residual symptoms interfering with usual activities; IV no improvement; $\mathrm{V}$ worse). The final outcome was classified as satisfactory if the patient had a satisfactory subjective review category (I or II) in addition to both a low obstructive symptom score $(0-3)$ and a low irritative symptom score (0-3).

Foint review by urologist and general practitioner-One hundred and sixty four patients were interviewed jointly by a general practitioner and consultant urologist who had not taken part in the previous interview. The format described above was repeated, but each interviewer gave his own subjective score for the patient (categories I to $\mathrm{V}$ ) without informing the other. The patient was then asked to indicate his present urinary symptoms on a linear analogue scale extending from zero to 100 in steps of 10 (100 representing complete success after the operation with no symptoms and zero representing no improvement or worsening of urinary symptoms compared with before the operation).

Statistical analysis-Descriptive data are reported as mean (SD) values, and $95 \%$ confidence intervals for differences in proportions were calculated for paired and unpaired samples. For ordinal variables the confidence intervals for differences between the means were also calculated from the standard error, even when distribution free tests were used because distributions were roughly symmetrical and the confidence intervals were included for descriptive purposes only. For paired data differences between symptom scores or the incidences of various symptoms before or after the operation were assessed by the $\mathrm{McNemar}$ change test for proportions and the Wilcoxon signed rank test for ordinal data. Associations between independent categorical variables were assessed by $\chi^{2}$ tests with Yates's correction. The Mann-Whitney U test and KruskalWallis tests were used to assess the effect of individual factors on the outcome of the operation. To establish which factors might influence the outcome and estimate the extent of their impact a discriminant function was developed, based on a stepwise selection of variables. The statistical package for the social sciences program "discriminant" was used. Two tailed $p$ values of 0.05 were taken as significant.

Approval for the study was obtained from the Newcastle District Ethical Committee.

\section{Results}

CLINICAL OUTCOME

Outcome based on symptoms

The severity of both obstructive and irritative symptoms decreased significantly after operation compared with before (symptom scores 1 (2) v 5 (2) for both; $\mathrm{p}<0.001)$. Table I gives details of the symptoms before and after operation. There was a significant improvement in all symptoms after operation $(p<0.001)$, but 
TABLE I-Symptoms in 216 men before and after prostatectomy. Figures are percentages (numbers)

\begin{tabular}{lccc}
\hline Symptoms & Before & After & $\begin{array}{c}\text { Mean difference } \\
(95 \% \text { confidence } \\
\text { interval })^{\star} \dagger\end{array}$ \\
\hline Poor stream & $82(177)$ & $18(39)$ & $64(57$ to 71$)$ \\
Hesitancy & $75(162)$ & $12(26)$ & $63(56$ to 70$)$ \\
Postmicturition dribble & $78(169)$ & $39(84)$ & $39(31$ to 47$)$ \\
Urgency & $69(149)$ & $32(68)$ & $37(28$ to 46$)$ \\
Nocturia & $58(125)$ & $19(4)$ & $39(31$ to 47$)$ \\
Urge incontinence & $29(63)$ & $10(21)$ & $19(12$ to 26$)$ \\
\hline${ }^{\star}$ Data analysed by McNemar's change test. & &
\end{tabular}

$t \mathrm{p}<0.001$ in each case.

some men after operation still had symptoms of poor flow (39), urgency (68), or urge incontinence (21).

On subjective review 171 men $(79 \%)$ were satisfied with the operation (subjective category I or II). The distribution of the categories was: I-117; II -54 ; III-35; IV-10; V-1. The symptom scores also showed that 171 men had both obstructive and irritative scores $<4$ but that 16 of the 171 men with a satisfactory subjective review had high symptom scores $(\geqslant 4)$.

On final review 155 men $(71 \%)$ satisfied all the criteria for a successful operation ( 171 with subjective category of I or II less 16 with high symptom scores.

\section{Reason for poor outcome}

The 62 men $(29 \%)$ whose outcome was less than satisfactory could be classified into two main groups; 32 had persistent, severe urgency of micturition with episodes of urge incontinence, and 27 men had poor urinary flow and their obstructive symptoms had improved little. The three remaining men had developed a urethral stricture or stenosis of the bladder neck and had persistent problems because of this. Eight additional men had had problems soon after the operation but nevertheless had done well at the final review: two had mild, temporary stress incontinence, four developed urethral strictures but were symptomless at the final review after treatment, and two with poor results had a further operation because it was thought that an inadequate operation had been performed by one particular trainee. No significant difference in outcome, however, was found among different surgeons, either in terms of who had listed the patient or who had performed the operation.

\section{Relation between preoperative symptoms and outcome}

Urge incontinence before operation ( $63 \mathrm{men}$ ) was the only symptom significantly associated with a poor outcome after operation, mainly because of persistent irritative symptoms and urge incontinence. Urge incontinence before operation was found in half $(16 / 32)$ of those who subsequently had a poor outcome because of persistent irritative symptoms, in $30 \%(8 / 27)$ of those with a poor outcome because of persistent poor flow, and in a quarter $(39 / 155)$ of those with a good outcome $\left(\chi^{2}=7 \cdot 9, \mathrm{df}=2 ; \mathrm{p}<0 \cdot 03\right)$.

Assessment of outcome by urologist and general practitioner

Table II shows the results of the joint review by a consultant urologist and general practitioner; substantial agreement was found between the two assessors, $91 \%$ of the men $(150 / 164)$ being classified similarly. The results of the linear analogue scale were broadly comparable with those of the subjective review, a good outcome (category I or II) being associated with a high analogue score (fig $1, \mathrm{r}_{\mathrm{s}}=-0.75 ; \mathrm{p}<0.001$ ).

RELATION BETWEEN URODYNAMIC MEASUREMENTS AND OUTCOME

Volume of prostate removed and ultrasonography of prostate

Before operation the volume of the prostate (adenoma plus capsule) measured by ultrasonography was smaller in men who subsequently had a poor outcome because of persistent symptoms of impaired urinary flow (mean volume $36(10) \mathrm{ml}$ ) than in men who did well (mean volume $56(40) \mathrm{ml}$ ) and in men who had persistent irritative symptoms (mean volume 48

TABLE II - Comparison between urologist and general practitioner of subjective category and symptom score. Figures are numbers of men

\begin{tabular}{|c|c|c|c|c|c|c|c|c|c|}
\hline & \multirow[b]{2}{*}{ Category } & \multicolumn{2}{|c|}{ Urologist } & \multirow[b]{2}{*}{ Total } & & \multirow{2}{*}{$\begin{array}{c}\text { Urologist } \\
\text { Symptom score }\end{array}$} & \multirow[b]{2}{*}{$0-3$} & \multirow[b]{2}{*}{$4-10$} & \multirow[b]{2}{*}{ Total } \\
\hline & & I/II & III-V & & & & & & \\
\hline General practitioner & $\left\{\begin{array}{l}\mathrm{I} / \mathrm{II} \\
\mathrm{III}-\mathrm{V}\end{array}\right.$ & $\begin{array}{r}125 \\
3\end{array}$ & $\begin{array}{l}11 \\
25\end{array}$ & $\begin{array}{r}136 \\
28\end{array}$ & General practitioner & $\left\{\begin{array}{l}0- \\
4-10^{\star}\end{array}\right.$ & $\begin{array}{r}117 \\
5\end{array}$ & $\begin{array}{l}10 \\
32\end{array}$ & $\begin{array}{r}127 \\
37\end{array}$ \\
\hline Total & & 138 & 36 & 164 & Total & & 122 & 42 & 164 \\
\hline
\end{tabular}

*Includes patients with either obstructive or irritative symptom score $\geqslant 4$.
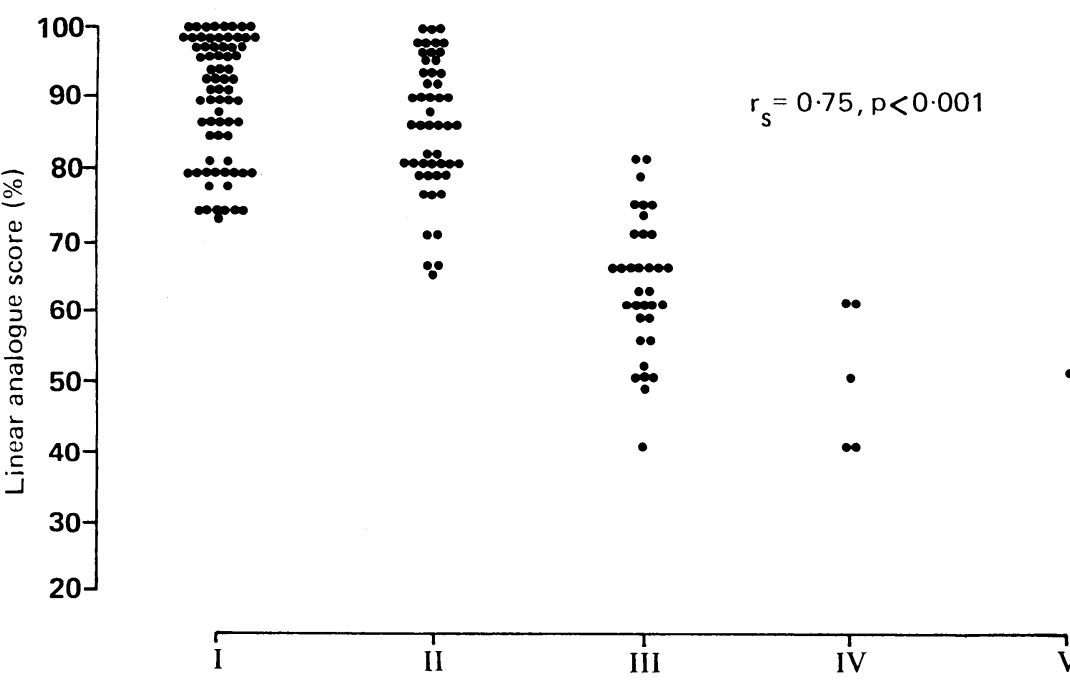

Subjective categories

FIG 1 -Correlation between subjective category given by urologist and linear analogue scale in 164 men having had prostatectomy
(14) $\mathrm{ml}$; Kruskal-Wallis $\mathrm{H}$ test $7 \cdot 49$; $\mathrm{p}<0 \cdot 03$ ). This finding was supported by the observation that the amount of tissue resected by transurethral prostatectomy was significantly less (about $10 \mathrm{~g}$ ) in such men (mean weight $13(5) \mathrm{g}$ ) compared with that in men who did well (mean weight $(24(13) \mathrm{g}$ ) and in men with persistent irritative symptoms (mean weight $22(14) \mathrm{g}$; Kruskal-Wallis $\mathrm{H}=16.49 ; \mathrm{p}<0.003)$. The outcome of prostatectomy in men with incidentally diagnosed prostatic cancer was not different compared with that in men with benign hyperplasia.

\section{Urinary flow rate and residual urine}

Maximum urinary flow rates were significantly improved after operation (table III, figs 2 and 3; $\mathrm{p}<0.0001$ ). Preoperative maximum urinary flow rates and residual urine volumes, however, were not associated with the outcome of operation. Table IV shows the effect of flow rates on outcome in men with or without detrusor instability: in neither group was there a suggestion that men with lower flow rates had a particularly good outcome. Moreover, 16 men (7\%) of 
the total of 214 had flow rates $\geqslant 15 \mathrm{ml} / \mathrm{s}$ when assessed in the urodynamic clinic despite all patients having flow rates $<15 \mathrm{ml} / \mathrm{s}$ in the outpatient department: the outcome after operation in these men was satisfactory, 15 patients having a good outcome (fig 2).

In men who had persistent symptoms of poor flow after operation $(n=26)$ a small but significant improvement in flow rates was found (rate before operation 8.9 (4) $\mathrm{ml} / \mathrm{s}$, rate after operation 12.6 (7) $\mathrm{ml} / \mathrm{s}$

TABLE III - Urodynamic evaluation of men before and after prostatectomy

\begin{tabular}{|c|c|c|c|}
\hline & Before & After & $\begin{array}{c}\text { Mean } \% \text { difference } \\
\text { (95\% confidence } \\
\text { interval) }\end{array}$ \\
\hline$\%$ (No) with instability (on filling) & $26(56 / 216)$ & $16(28 / 178)$ & $10(2 \text { to } 18)^{\star}$ \\
\hline$\%$ (No) with instability (provoked) & $48(104 / 216)$ & $26(46 / 179)$ & $22(13 \text { to } 31)^{\star}$ \\
\hline Mean (SD) peak flow $\left(\mathrm{ml}^{\prime} \mathrm{s}\right)(\mathrm{n}=205)$ & $9(6)$ & $18(12)$ & $-8.9(7 \cdot 8 \text { to } 10)^{\star}$ \\
\hline Mean $(\mathrm{SD})$ voided volume $(\mathrm{ml})(\mathrm{n}=205)$ & $221(120)$ & $340(156)$ & $-119(96 \text { to } 142)^{\star}$ \\
\hline Mean $(\mathrm{SD})$ residual urine $(\mathrm{ml})(\mathrm{n}=207)$ & $196(350)$ & $67(160)$ & $129(88 \text { to } 170)^{\star}$ \\
\hline Mean $(\mathrm{SD})$ cystometric capacity $(\mathrm{ml})(\mathrm{n}=181)$ & $330(154)$ & $412(145)$ & $-82(63 \text { to } 101)^{\star}$ \\
\hline Mean (SD) pressure rise $\left(\mathrm{cm} \mathrm{H}_{2} \mathrm{O}\right)$ during filling $(\mathrm{n}=181)$ & $15(15)$ & $16(13)$ & $-1(-3$ to 1$) t$ \\
\hline Mean (SD) micturition pressure $\left(\mathrm{cm} \mathrm{H}_{2} \mathrm{O}\right)(\mathrm{n}=179)$ & $100(44)$ & $61(31)$ & $39(32 \text { to } 46)^{\star}$ \\
\hline Mean (SD) urethral resistance $\left(\mathrm{cm} \mathrm{H}_{2} \mathrm{O} . \mathrm{s}^{-} \cdot \mathrm{ml}^{\circ}\right)(\mathrm{n}=179)$ & $4 \cdot 3(9)$ & $0.4(0 \cdot 6)$ & $3 \cdot 9(2 \text { to } 6)^{\star}$ \\
\hline
\end{tabular}

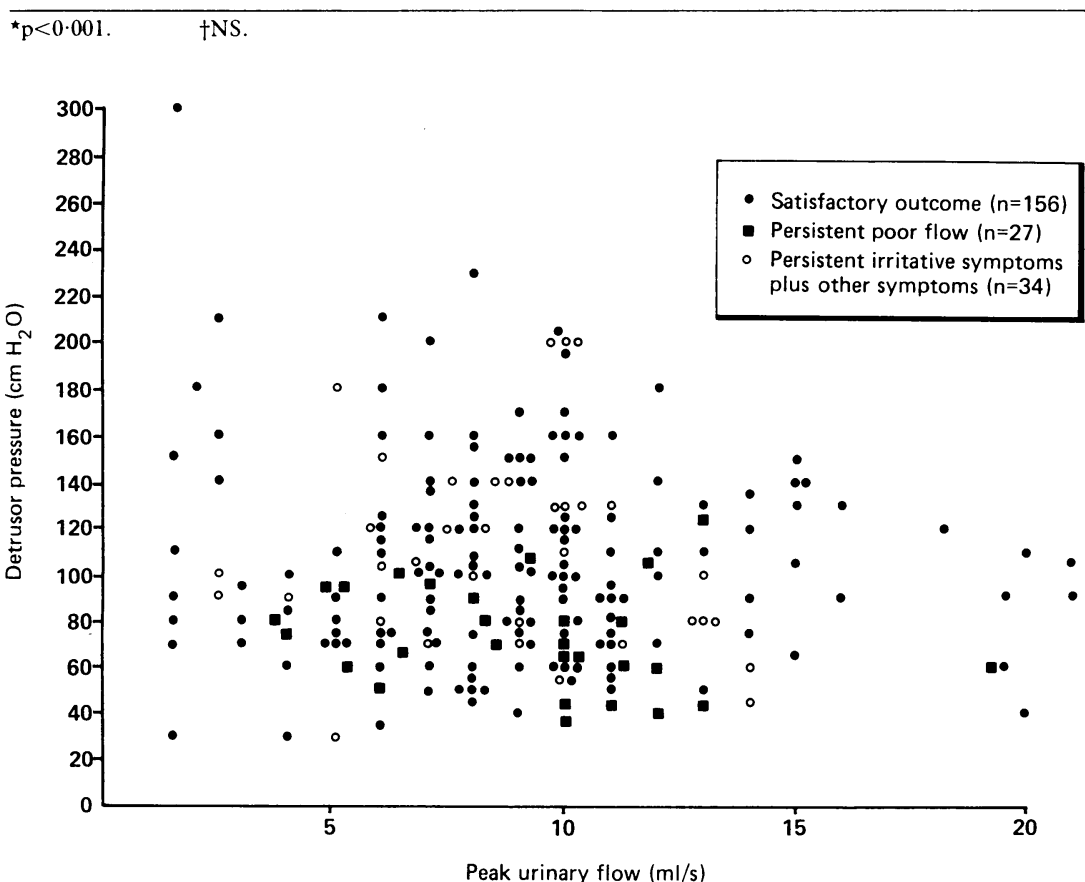

FIG 2-Preoperative detrusor pressure at maximum flow and peak urinary flow according to final outcome after operation in 217 men

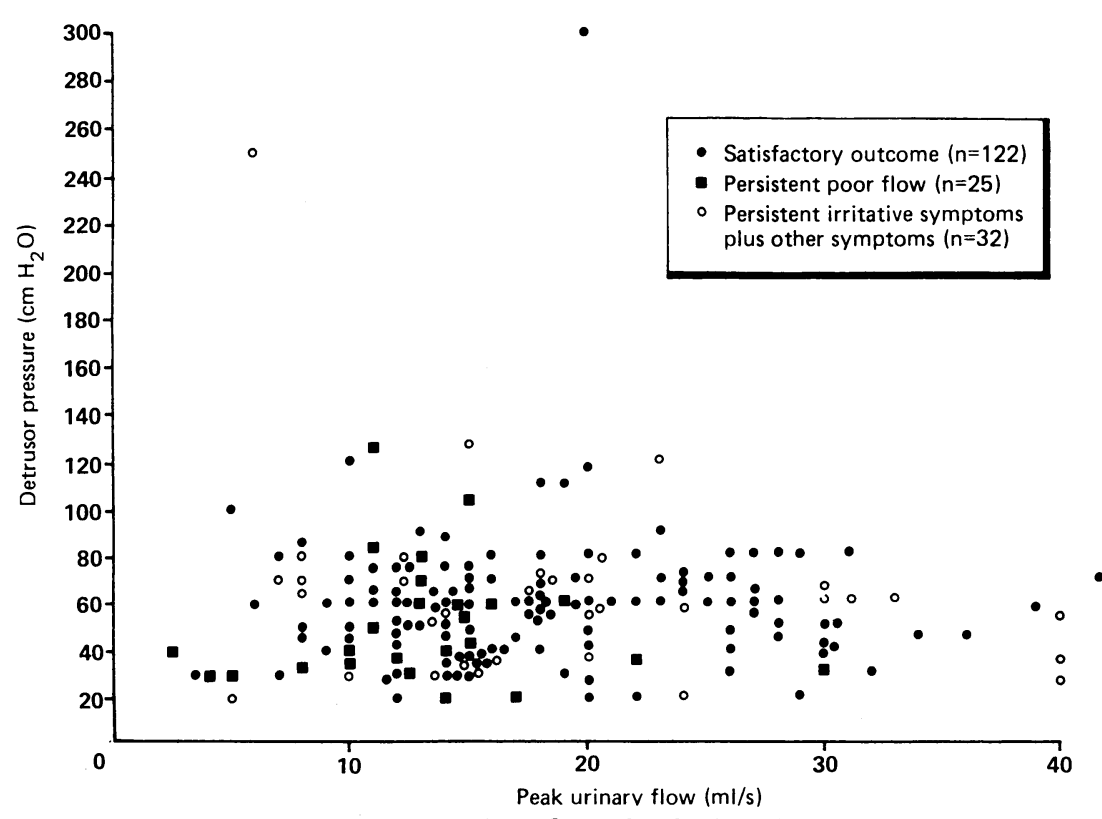

FIG 3-Postoperative detrusor pressure at maximum flow and peak urinary flow according to final outcome in 179 men (scale of horizontal axis is half that in fig 2) $(\mathrm{p}<0.002)$, mean difference $3.7 \mathrm{ml} / \mathrm{s}$ (confidence interval 1.7 to $4.6 \mathrm{ml} / \mathrm{s}$ )). In contrast, in men who did well after operation maximum flow rates were improved compared with before the operation $(8 \cdot 9$ (4) $\mathrm{ml} / \mathrm{s}(\mathrm{n}=157)$ v 18.8 (9) $\mathrm{ml} / \mathrm{s}(\mathrm{n}=150)$; mean difference $9.9 \mathrm{ml} / \mathrm{s}$, confidence interval 8.6 to 11.2 $(\mathrm{n}=148) ; \mathrm{p}<0.001)$ and in men who had persistent irritative symptoms $(8.5(3) \mathrm{ml} / \mathrm{s}(\mathrm{n}=32) v 17 \cdot 4(8) \mathrm{ml} / \mathrm{s}$ $(\mathrm{n}=31)$; mean difference $8.9 \mathrm{ml} / \mathrm{s}$, confidence interval $6 \cdot 2$ to $11 \cdot 6(\mathrm{n}=31) ; \mathrm{p}<0 \cdot 001)$. Maximum flow rates after operation and the change in flow rates after operation compared with beforehand in men with symptoms of poor flow were significantly lower than in the remainder (Kruskal-Wallis, $\mathrm{p}<0.001$ ).

\section{Urodynamic findings}

Table III shows changes in urodynamic measurements after operation. A poor outcome based on symptoms was associated with low voiding pressures or low urethral resistances before operation and low maximum urinary flow rates after operation (figs 2 and 3). These associations were clarified further when men with a poor outcome were classified into those with persistent poor flow or those with persistent irritative symptoms (table V). The group with poor flow had lower voiding pressures and urethral resistances before operation, lower flow rates after operation, and lower rates of detrusor instability compared with those with irritative symptoms. Tables VI and VII present these results in an alternative way and show the outcome in relation to the voiding pressures and urethral resistances subclassified according to the presence of detrusor instability. The relation among low voiding pressure, low urethral resistance, and a poor outcome because of symptoms of poor flow was confined to men with stable detrusors. In contrast, men with detrusor instability were likely to do less well after operation because of symptoms of urge or urge incontinence.

Ten men after operation still had increased voiding pressures $\left(>80 \mathrm{~cm} \mathrm{H}_{2} \mathrm{O}\right)$ and low flow rates $(<10 \mathrm{ml} / \mathrm{s})$ and four had a poor outcome (fig 3 ).

TABLE IV - Relation between preoperative maximum urinary flow rate and outcome in men with or without detrusor instability

\begin{tabular}{lcc}
\hline & \multicolumn{2}{c}{ Maximum flow rate $(\mathrm{ml} / \mathrm{s})$} \\
\cline { 2 - 3 } & $<10$ & $>10$ \\
\hline \multicolumn{3}{c}{ With stable detrusor $(n=111)^{\star}$} \\
Success $(\mathrm{n}=83)$ & 64 & 19 \\
Poor flow $(\mathrm{n}=16)$ & 9 & 7 \\
Irritative symptoms $(\mathrm{n}=12)$ & 11 & 1 \\
\multicolumn{4}{l}{$\quad$ With unstable detrusor $(n=103) \dagger$} & \\
Success $(\mathrm{n}=73) \quad 50$ & 23 \\
Poor flow $(\mathrm{n}=10) \quad$ & 8 & 2 \\
Irritable symptoms $(\mathrm{n}=20)$ & 14 & 6 \\
\hline
\end{tabular}

$\gamma^{\prime}=5 \cdot 0, \mathrm{df}=2 ; \mathrm{p}=0 \cdot 08$.

$+\gamma^{\prime}=0 \cdot 6, \mathrm{df}=2 ; \mathrm{NS}$.

TABLE V-Urodynamic findings in men with poor outcome

\begin{tabular}{|c|c|c|}
\hline & $\begin{array}{l}\text { Men with } \\
\text { persistent } \\
\text { poor flow } \\
\text { plus } \\
\text { no better }\end{array}$ & $\begin{array}{l}\text { Men with } \\
\text { persistent } \\
\text { irritative } \\
\text { symptoms } \\
\text { and others }\end{array}$ \\
\hline \multicolumn{3}{|l|}{ Mean (SD) voiding pressures $\left(\mathrm{cm} \mathrm{H}_{2} \mathrm{O}\right)$ : } \\
\hline Preoperative & $\begin{array}{l}80(39) \\
(n=26)\end{array}$ & $\begin{array}{c}106(44)^{\star \star} \\
(\mathrm{n}=33)\end{array}$ \\
\hline Postoperative & $\begin{array}{l}53(29) \\
(\mathrm{n}=26)\end{array}$ & $\begin{array}{c}68(45)^{\star} \\
(n=31)\end{array}$ \\
\hline Mean (SD) postoperative flow rate $(\mathrm{mL} / \mathrm{s})$ & $\begin{array}{l}13(5) \\
(n=26)\end{array}$ & $\begin{array}{l}17(7)^{\star \star} \\
(\mathrm{n}=32)\end{array}$ \\
\hline \multicolumn{3}{|l|}{$\%(\mathrm{No})$ with instability on filling: } \\
\hline Preoperative & $15(4 / 27)$ & $51(18 / 35)^{\star \star}$ \\
\hline Postoperative & $17(4 / 24)$ & $42(13 / 31) \dagger$ \\
\hline \multicolumn{3}{|l|}{$\%$ (No) with provoked instability: } \\
\hline Preoperative & $37(10 / 27)$ & $66(23 / 35)^{\star}$ \\
\hline Postoperative & $21(5 / 24)$ & $51(17 / 31)^{\star}$ \\
\hline
\end{tabular}


Predicting outcome of prostatectomy

Before operation urge incontinence', low voiding pressures, low urethral resistance, detrusor instability, and small size of prostate were signifirantly associated with a poor outcome after operation because of either poor flow or persistent urgency. Table VIII shows the cumulative effect of these factors in developing a multivariate discriminant function and table IX the sensitivity and specificity of the discriminant function in predicting accurately the different outcomes of operation. The apparently high degree of specificity in defining the successful group is, in part, related to the large number of patients in the successful group compared with the small numbers in the other two groups. Most importantly, though, the sensitivity of the discriminant function in defining the successful group was only $48 \%$.

\section{Discussion}

This prospective study confirms that for most men prostatectomy provides good relief of symptoms and is associated with satisfactory improvement in uro-

TABLE VI-Relation between preoperative voiding pressure ${ }^{\star}$ and outcome in men with or without detrusor instability

\begin{tabular}{|c|c|c|c|}
\hline \multirow[b]{2}{*}{ Outcome } & \multicolumn{3}{|c|}{ Voiding pressure $\left(\mathrm{cm} \mathrm{H}_{2} \mathrm{O}\right)$} \\
\hline & $<80$ & $80-100$ & $>100$ \\
\hline \multicolumn{4}{|c|}{ With stable detrusor $(n=111) t$} \\
\hline Success $(\mathrm{n}=83)$ & 31 & 14 & 38 \\
\hline Poor flow $(n=16)$ & 14 & l & 1 \\
\hline Irritative symptoms $(n=12)$ & 7 & $i$ & 4 \\
\hline \multicolumn{4}{|c|}{ With unstable detrusor $(n=104) \neq$} \\
\hline Success $(n=74)$ & 23 & 15 & 36 \\
\hline Poor flow $(n=10)$ & 4 & 4 & 2 \\
\hline Irritative symptoms ( $\mathrm{n}=20$ ) & 5 & 5 & 10 \\
\hline
\end{tabular}

TABLE VII - Relation between preoperative maximum urethral resistance ${ }^{\star}$ in men with or without detrusor instability

\begin{tabular}{|c|c|c|c|}
\hline & \multicolumn{3}{|c|}{ Maximum urethral resistance } \\
\hline & $<0 \cdot 5$ & $0 \cdot 5-1 \cdot 0$ & $>1 \cdot 0$ \\
\hline \multicolumn{4}{|c|}{ With stable detrusor $(n=110) f$} \\
\hline Success $(n=82)$ & 8 & 27 & 47 \\
\hline Poor flow $(n=16)$ & 8 & 4 & 4 \\
\hline Irritative symptoms $(\mathrm{n}=12$ ) & 0 & 4 & 8 \\
\hline \multicolumn{4}{|c|}{ With unstable detrusor $(n=103 \neq$} \\
\hline Success $(n=73)$ & 10 & 17 & 46 \\
\hline Poor flow $(n=10)$ & 0 & 3 & 7 \\
\hline Irritative symptoms $(n=20)$ & 4 & 1 & 15 \\
\hline
\end{tabular}

^Detrusor pressure at maximum flow/maximum flow rate.

t $x:=20 \cdot 2$, df $=4 ; \mathrm{p}=0 \cdot 0005$.

$\mp \gamma=5 \cdot 4, \mathrm{df}=4$; NS.

TABLE VIII - Multivariate discriminant analysis relating postoperative outcome to preoperative symptoms and urodynamic variables

\begin{tabular}{lrc}
\hline & $\begin{array}{c}\text { Changes in } \\
\text { Rao's V }\end{array}$ & Significance \\
\hline Urge incontinence & $10 \cdot 085$ & 0.0065 \\
Voiding pressure & $8 \cdot 380$ & 0.0151 \\
Urethral resistance & $11 \cdot 989$ & 0.0025 \\
Detrusor instability & $7 \cdot 279$ & 0.0263 \\
Volume of prostate resected & $5 \cdot 184$ & 0.0749 \\
\hline
\end{tabular}

TABLE IX - Sensitivity and specificity of predictive index derived from discriminant analysis

\begin{tabular}{lcc}
\hline Outcome & $\begin{array}{c}\text { Sensitivity } \\
(\%)\end{array}$ & $\begin{array}{c}\text { Sensitivity } \\
(\%)\end{array}$ \\
\hline Success & $48 \cdot 4$ & $84 \cdot 2$ \\
Poor flow and unimproved obstructive & $69 \cdot 2$ & $74 \cdot 2$ \\
symptoms & $51 \cdot 6$ & $74 \cdot 6$ \\
\hline Urgency and urge incontinence & & \\
\hline
\end{tabular}

dynamic measurements. Furthermore, only one man died, and in only a handful was their condition unimproved or made worse: these reassuring findings agree with previous studies. 369412 An appreciable minority of men, however, despite recording some slight improvements were left with persistent symptoms of lower urinary tract dysfunction.

The second main finding was that urodynamic studies did not predict the outcome of prostatectomy, although when performed after operation they often explained why the patient had persistent symptoms. Certain variables measured before operation were associated with poor outcome, and in particular our initial hypothesis - that men with low or normal voiding pressure may not do as well after prostatectomy - was supported by the study. Defining the grade of obstruction by more advanced computer models relating pressure and flow ${ }^{17}$ may lead to better prognostic functions being developed.

Measuring outcome after operation is never easy because patient and surgeon are hoping for success, but the patients in our study were reviewed by a urologist and a general practitioner to try to obtain an independent and critical assessment of the results. Symptoms may persist after operation because of failure of operative technique, because of poor patient selection, or because the symptoms were not caused by abnormalities that the operation could correct. Poor technical performance seems unlikely to have been responsible in most patients who had persistent symptoms. No evidence was found relating outcome to the surgeon performing the operation. In addition, an inadequately performed operation would not explain the observation that certain findings before operation were associated with a poor result subsequently.

The main hypothesis was that men with low or normal voiding pressure before operation would not do as well after operation as those with high voiding pressures. Expressed simply, their symptoms might have been caused mainly by poor detrusor contraction rather than outflow obstruction and would not therefore respond to an operation designed to relieve obstruction. Few prospective studies have highlighted this group of men, although Jensen $e t$ al found a greater risk of a poor result when the preoperative urodynamic study suggested non-obstructed bladder outflow ${ }^{12}$; a smaller study failed to find an effect on outcome of preoperative voiding pressures. ${ }^{1 \times}$ Rather to our surprise, in men who did not do well because of symptoms of poor flow the weight of the resected prostate was less, which was commensurate with their preoperative prostatic volumes. ${ }^{120}$ Though men with small prostates undoubtedly may have severe bladder outflow obstruction, ${ }^{21}$ a recent study found that men with small fibrous prostates were less likely to do well after prostatectomy.2.

The other main reason for a less than satisfactory outcome was that some men had persistent symptoms of frequency, urgency, and urge incontinence, and these were associated with detrusor instability before operation. This finding has been reported previously, ${ }^{23.25}$ though we found that most men with detrusor instability who had symptoms and a flow rate of $<15 \mathrm{ml} / \mathrm{s}$ did well after operation.

In contrast with Abrams, ${ }^{8}$ we failed to find that low maximum urinary flow rates before operation were an important predictor of outcome. One of our criteria for selecting men for operation was a flow rate of less than $15 \mathrm{ml} / \mathrm{s}$, and we might have selected out already the patients in whom this criterion was going to be important. Several reported findings, however, do not support this argument. Firstly, a study in North America, in which patients were selected primarily on the basis of symptoms, failed to show any effect of flow rates on outcome. ${ }^{26}$ Secondly, several of our patients 
had urinary flow rates of $15 \mathrm{ml} / \mathrm{s}$ or more despite our aiming at excluding them: the outcome in this group was satisfactory, in agreement with previous studies. ${ }^{26-28}$ On the other hand, Jensen et al recently reported that urinary flow rates above $15 \mathrm{ml} / \mathrm{s}$ were associated with a poor outcome (5/17) compared with the remainder $(10 / 117),{ }^{12}$ but the numbers were small and most men with high flow rates did well.

Most men contemplating the prospect of prostatectomy should be reassured by our study. There is, however, a clear need to identify beforehand that quarter of men who do not benefit greatly from the operation. Though the performance of a speculative prostatectomy as a diagnostic test is unsatisfactory, urodynamic studies, as presently carried out, do not seem to hold the key to this problem.

We thank Mr D M Essenhigh and Mr R R Hall for permission to study their patients, and Sister $M$ Burns and Miss A S Gallaugher for their help in performing the urodynamic studies and organising the postoperative reviews.

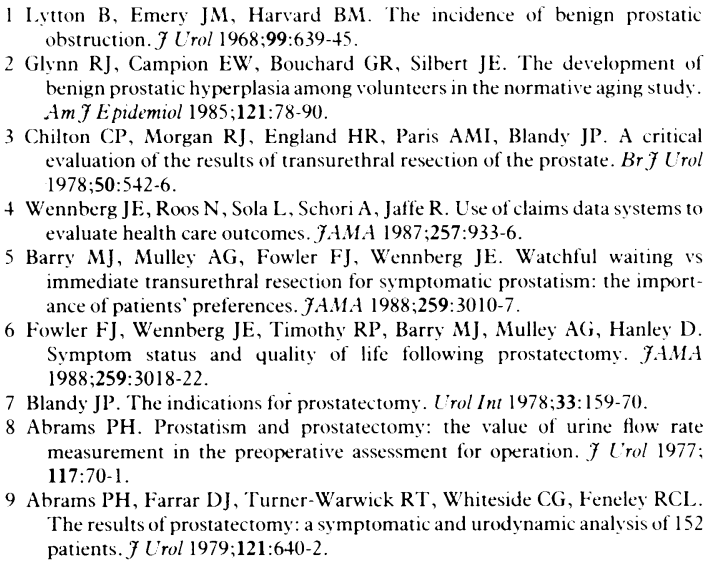

3 Chilton CP, Morgan RJ, England HR, Paris AMI, Blandy JP. A critical evaluation of the results of transurethral resection of the prostate. $\mathrm{Br} 7 \mathrm{Crol}$ 1978;50:5+2-6.

4 Wennberg JE, Roos N, Sola L, Schori A, Jaffe R. Use of claims data systems to evaluate health care outcomes. $7 A M A$ 1987;257:933-6.

5 Barry MJ, Mulley AG, Fowler FJ, Wennberg JE. Watchful waiting vs immediate transurethral resection for symptomatic prostatism: the import ance of patients' preferences. $\mathcal{F} A M A$ 1988;259:3010-7.

6 Fowler FJ, Wennberg JE, Timothy RP, Barry MJ, Mulley A(j, Hanley D Svmptom status and quality of life following prostatectoms. F $\mathrm{A} \mathrm{M}_{\mathrm{i}}$ 1988;259:3018-22.

7 Blandy JP. The indications for prostatectomy. Urol Int 1978:33:159-70.

8 Abrams PH. Prostatism and prostatectomy. the value of urine flow rate measurement in the preoperative assessment for operation. F C rol 1977 measurem $1170-1$.

9 Abrams PH, Farrar DJ, Turner-Warwick RT, Whiteside CG, Fenelev RCL. The results of prostatectomy: a sumptomatic and urodynamic anal'sis of 152 patients. F Urol 1979;121:6+0-2.

10 Andersen JT. Prostatism: III. Detrusor hyperreflexia and residual urine. Clinical and urodsnamic aspects and the influence of surgers on the prostate. Siand F C rol Nephrol 1982;16:25-30.

11 Bruskewitz R, Jensen KM-F, Iversen P, Madsen PO. The relevance of minimum urethral resistance in prostatism. 7 L rol 1983;129:769-71.

12 Jensen K.M-E. Jorgensen JB, Mogensen P. Urodynamics in prostatism: parts I-IV Scand f ['rol Vephrol S Suppl] 1988:114:63-86.

13 Neal DE, Strles RA, Ng T. Powell PH, Thong J, Ramsden PID. The relationship between voiding pressures, symptoms and urodynamic findings in 253 men undergoing prostateciomy: Br f L V rol 1987:60:554-9.

14 Neal DE, Strles RA, Powell PH, Ramsden PD. The relationship between detrusor function and residual urine in men undergoing prostatectoms. Bry C'rol 1987;60:560-6.

15 Bates CP, Bradley WE, Glen E, et al. The standardisation of terminology of lower urinary tract function. 7 Urol 1979;121:551-4.

16 Frimodt-Moller PC, Jensen KM-E, Iversen P, Madsen PO, Bruskewitz RC Analysis of presenting symptoms in prostatism. 7 Urol 1984;132:272-6.

17 Schäfer W. Urethral resistance: urodynamic concepts of physiological and pathological bladder outlet function during voiding. Neurologv and Urodynamics 1985:4:161-201.

18 Jensen KM-E, Bruskewitz RC, Iversen P', Madsen PO. Predictive value of voiding pressures in benign prostatic hyperplasia. Neurology and Urodynamics 1983:2:117-25

19 Mivazaki Y, Yamaguchi A, Hara S. The value of transrectal ultrasonography in preoperative assessment for transurethral prostatectomy. 7 Urol 1983; in preoperatic

20) Walz $\mathrm{PH}$, Wenderoth U, Jacobi GH. Suprapubic transvesical sonography of the prostate: determination of prostate size. Eur Eurol 1983;9:148-52

21 Turner-Warwick RT, Whiteside CG, Arnold EP, et al. A urodynamic view of prostatic obstruction and the results of prostatectomy. Br f Crol 1973;45: $631-45$.

22 Dorflinger T, England DM, Madsen P(), Bruskewitz RC. Urodynamic and histological correlates of benign hyperplasia. f Urol 1988; 140:1487-90.

23 Cote RJ, Burke H, Schoenberg HW. Prediction of unusual postoperative results by urodvnamic testing in henign prostatic hyperplasia. f Urol 1981;125:690-2.

24 Dorflinger T, Frimodt-Moller PC, Bruskewitz RC, Jensen KM-E, Iversen P, Madsen PO. The significance of uninhibited detrusor contractions in prostatism f L'rol 1985:133:819-21.

25 Fitzpatrick JM, Gardiner RA, Worth PHL. The evaluation of 68 patients with post-prostatectomy incontinence. Br f C rol 1979:51:552-5.

26 Dorflinger T, Bruskewitz RC, Jensen KM-E, Iversen P, Madsen PO. Predictive value of low maximum flow rates in benign prostatic hyperplasia. Predictive value of low
Urology 1986;27:569-73.

27 Gerstenberg TC, Andersen JT, Klarskov P, Ramirez D, Hald T. High flow infravesical obstruction in men: symptomatology, urodynamics and the results of surgery. 7 L'rol 1982;127:943-5.

28 Iversen P, Bruskewitz RC, Jensen KM-E, Madsen PO. Transurethral resection in the treatment of prostatism with high urinary flow. $\mathcal{J}$ Urol $1983 ; 129: 995-7$

Accepted 17 fuly 1989

\section{Obesity Research Group, \\ Hvidovre University \\ Hospital, DK-2650 \\ Copenhagen \\ Stig Sonne-Holm, CANDMED, senior registrar \\ Thorkild I A Sørensen, \\ DRMED, chief physician \\ Copenhagen City Heart Study, Rigshospitalet, DK-2100 Copenhagen Gorm Jensen, DRMED, chief physician \\ Peter Schnohr, CANDMED, chief physician \\ Correspondence and requests for reprints to: Dr S Sonne-Holm, L E Bruuns vej 27, Charlottenlund, DK-2920 Copenhagen, Denmark.}

BrMed 7 1989;299:767-70

\title{
24 Independent effects of weight change and attained body weight on prevalence of arterial hypertension in obese and non-obese men
}

\author{
Stig Sonne-Holm, Thorkild I A Sørensen, Gorm Jensen, PetetSchnohr
}

Abstract

52 Objective-To assess the relations among prevalence of arterial hypertension, history of weight change, and current body weight in the range from normal weight to severe obesity.

Design-Retrospective analysis of medical records of men registered with Danish military authorities from 1943 to 1977 and followed up four to 40 years later.

Setting-Draft board of Copenhagen and surrounding counties and the rest of Sjaelland and surrounding islands.

Subjects-964 Men who were severely obese (body mass index $\geqslant 31 \mathrm{~kg} / \mathrm{m}^{2}$ at the first examination) and 1134 random controls.

Main outcome measures-Blood pressure and weight.

Results-Hypertension was more prevalent in subjects with an unchanged body mass index as that index increased over the range studied. At any body mass index hypertension was more prevalent in subjects who had increased to this index and less common in those who had decreased to it than in those who had stayed the same weight since the first examination. Hypertension among controls was most common in those subjects who had become obese during adulthood.

Conclusions-Changes in body weight have a great influence on arterial hypertension independent of the effect of attained weight, particularly in obese subjects.

\section{Introduction}

Several prospective clinical studies have shown a correlation between change in weight and blood pressure in severely obese patients treated with diet or a bariatric operation..$^{1-3}$ This effect is so pronounced that a reducing diet is considered a rational treatment of moderate hypertension in obese subjects. ${ }^{+5}$ The mechanism of the close relation between body weight and blood pressure is not fully clarified. ${ }^{\circ}$ One major unsolved question is whether the blood pressure after changes in body weight corresponds to the predicted blood pressure for the attained body weight. If it does the body composition as such rather than the effects of the changes in body weight is essential to the blood pressure. This is particularly important in the understanding of the association between obesity and hypertension. 